\title{
Improved Multimodal Emotion Recognition for Better Game-Based Learning
}

Citation for published version (APA):

Bahreini, K., Nadolski, R., \& Westera, W. (2015). Improved Multimodal Emotion Recognition for Better GameBased Learning: For OULUU Team from Finland, December 9, 2014, Heerlen, the Netherlands.

Document status and date:

Published: 15/01/2015

Document Version:

Peer reviewed version

Document license:

CC BY-NC-SA

Please check the document version of this publication:

- A submitted manuscript is the version of the article upon submission and before peer-review. There can be important differences between the submitted version and the official published version of record. People interested in the research are advised to contact the author for the final version of the publication, or visit the DOI to the publisher's website.

- The final author version and the galley proof are versions of the publication after peer review.

- The final published version features the final layout of the paper including the volume, issue and page numbers.

Link to publication

\section{General rights}

Copyright and moral rights for the publications made accessible in the public portal are retained by the authors and/or other copyright owners and it is a condition of accessing publications that users recognise and abide by the legal requirements associated with these rights.

- Users may download and print one copy of any publication from the public portal for the purpose of private study or research.

- You may not further distribute the material or use it for any profit-making activity or commercial gain

- You may freely distribute the URL identifying the publication in the public portal.

If the publication is distributed under the terms of Article $25 f a$ of the Dutch Copyright Act, indicated by the "Taverne" license above, please follow below link for the End User Agreement:

https://www.ou.nl/taverne-agreement

Take down policy

If you believe that this document breaches copyright please contact us at:

pure-support@ou.nl

providing details and we will investigate your claim.

Downloaded from https://research.ou.nl/ on date: 26 Apr. 2023 


\title{
Improved Multimodal Emotion Recognition for Better Game-Based Learning
}

\author{
Kiavash Bahreini \\ Dr. Rob Nadolski \\ Prof. dr. Wim Westera
}

For OULU Team from Finland, December 9,2014,

Heerlen, The Netherlands 


\section{Agenda}

1. What is this research about?

2. What is the target group?

3. Why this research?

4. How to do this research?

5. What have been done so far?

1. Framework, participants, and software

2. Experiment

3. Results

6. Future direction 


\section{What is this research about?}

1. Multimodal emotion recognition from two sources:

1. Face and voice

1. Happy, sad, fear, disgust, surprise, angry, and neutral

2. Learner support in serious games:

1. Enhancing online communication skills training

2. Self-awareness of own behavior

3. Provide timely and adequate feedback 


\section{What is the target group?}

\section{Life long learners}

(learners who are interested in improving communication skills using emerging technologies) 


\section{Why are we doing this research?}

1. The importance of communication skills in knowledge society nowadays

2. Market demands

3. Communication-skills are high priority at EU level 1 , 2, 3, 4

4. Provide an attractive environment with regard to gamebased learning

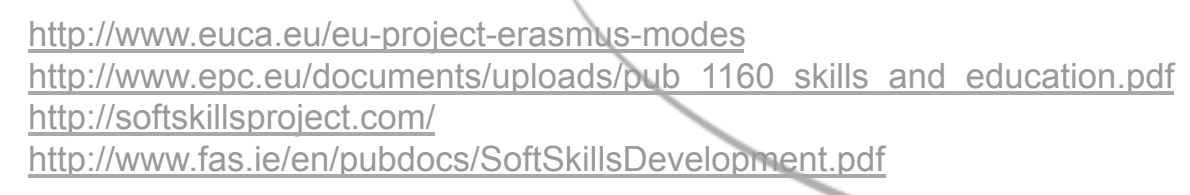




\section{How to do this research?}

1. Using devices and modern equipment

- Webcams and microphones

2. Some developments: The overarching framework and software

3. Gather facial and vocal emotions in real-time

4. Integrate the software artifacts with a gamebased engine:

1. EMERGO (a game-based toolkit for delivery of multimedia cases ) 


\section{What have been done so far?}

\section{Welten Institute}

Research Centre for Learning, Teaching and Technology 


\section{Layers of FILTWAM}

\section{Learner}

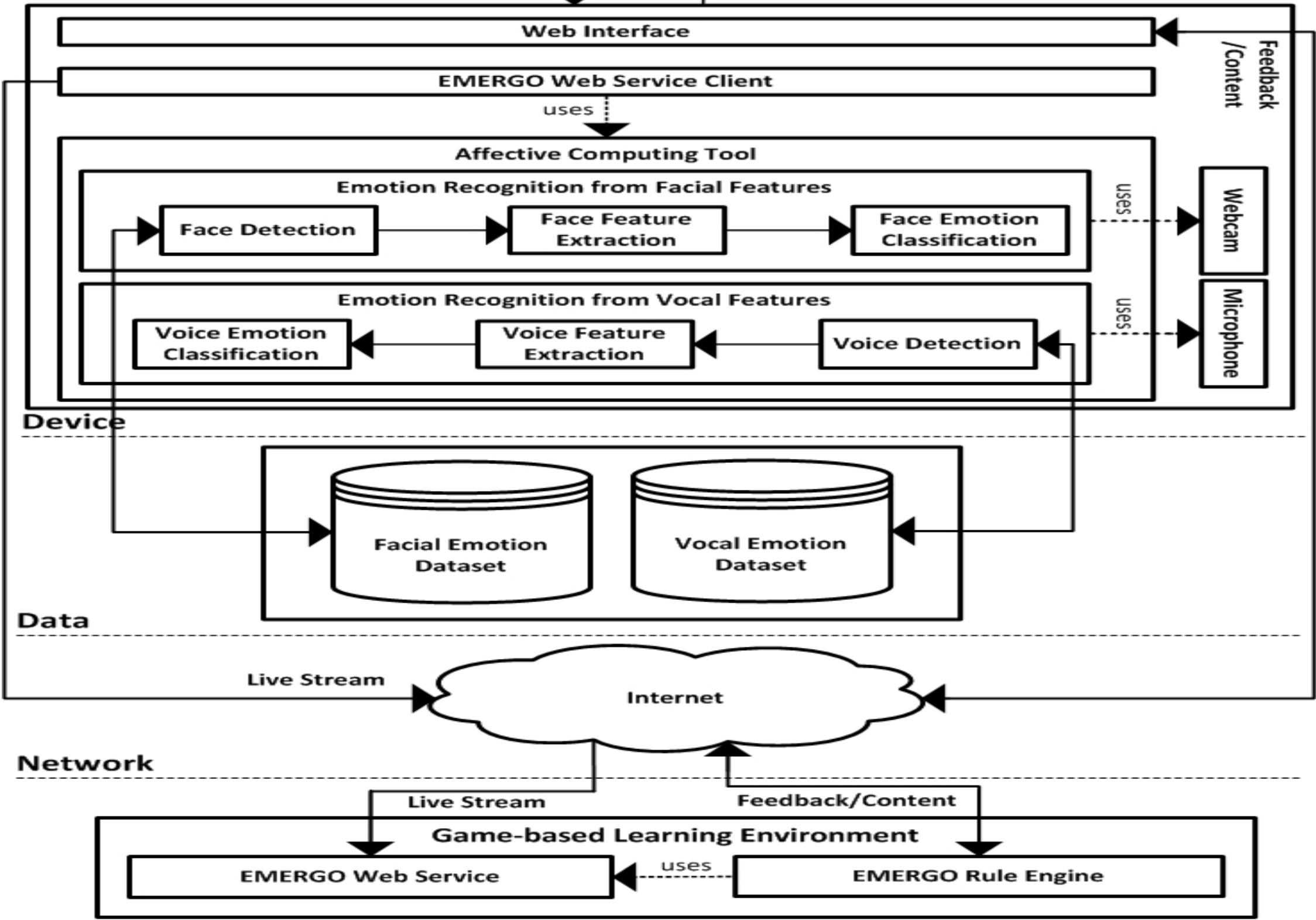

\section{Application}




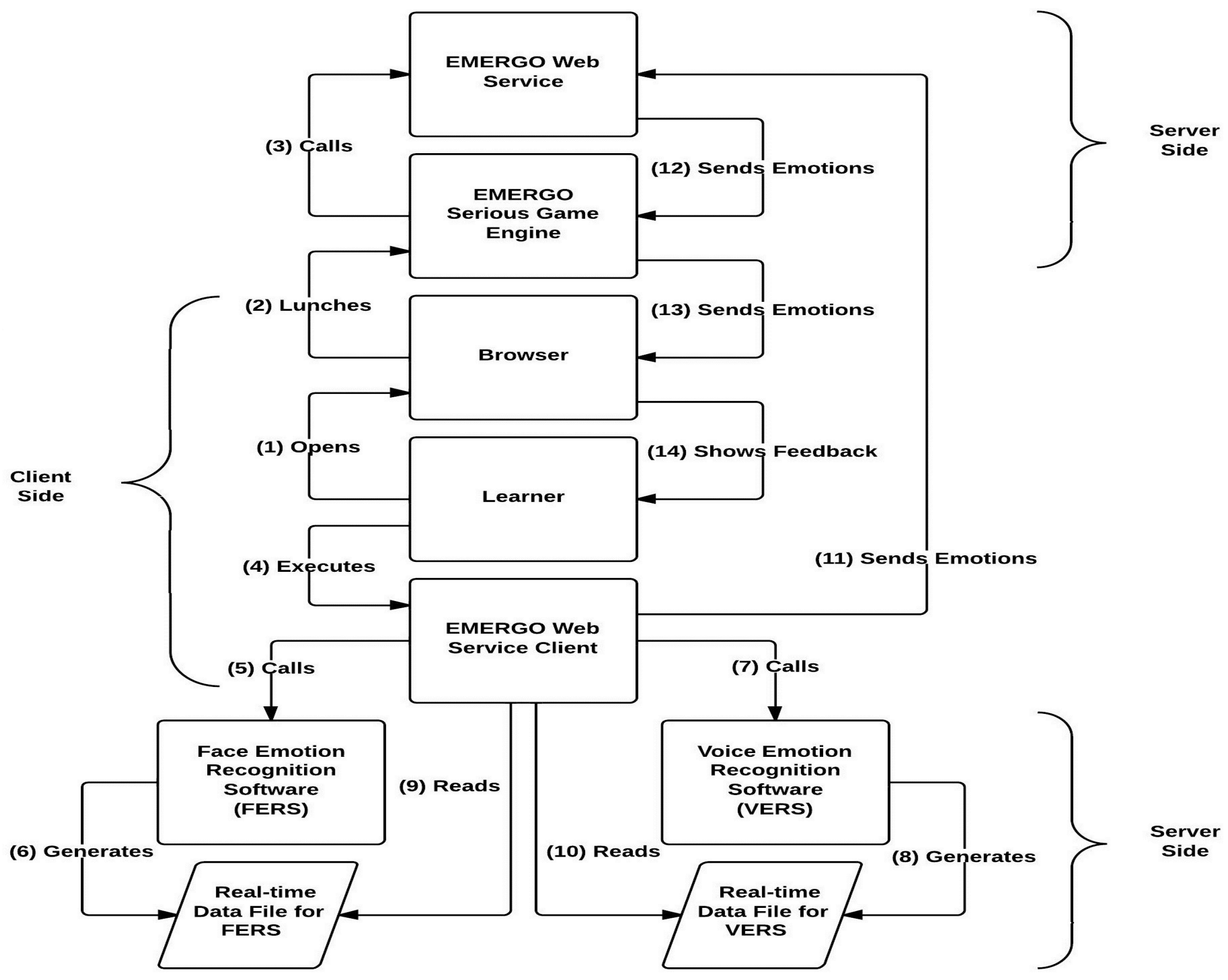




\section{Participants and tasks}

- Twelve participants ( 7 male, 5 female; age $M=42, S D=10$ )

- Four consecutive tasks were given to the participants:

- Mimic and repeat loudly the emotion that was presented through PowerPoint slides,

- Mimic and repeat loudly the seven voice expressions,

- Slides presented a text transcript (both sender and receiver) taken from a good-news conversation, participants were requested to read and speak aloud the sender 'slides' of transcript,

- as in task 3 , but in this case the text transcript was taken from a bad-news conversation 


\section{Participants' opinions}

1. All tasks were moderately difficult and interesting to do

2. Instructions were clear

3. The feedback was pretty helpful

4. The self-assurance factor was not high among the participants

5. There was no distraction during the performance

6. The participants did not regard themselves as actors 


\section{Validation results of the face emotion recognition software}

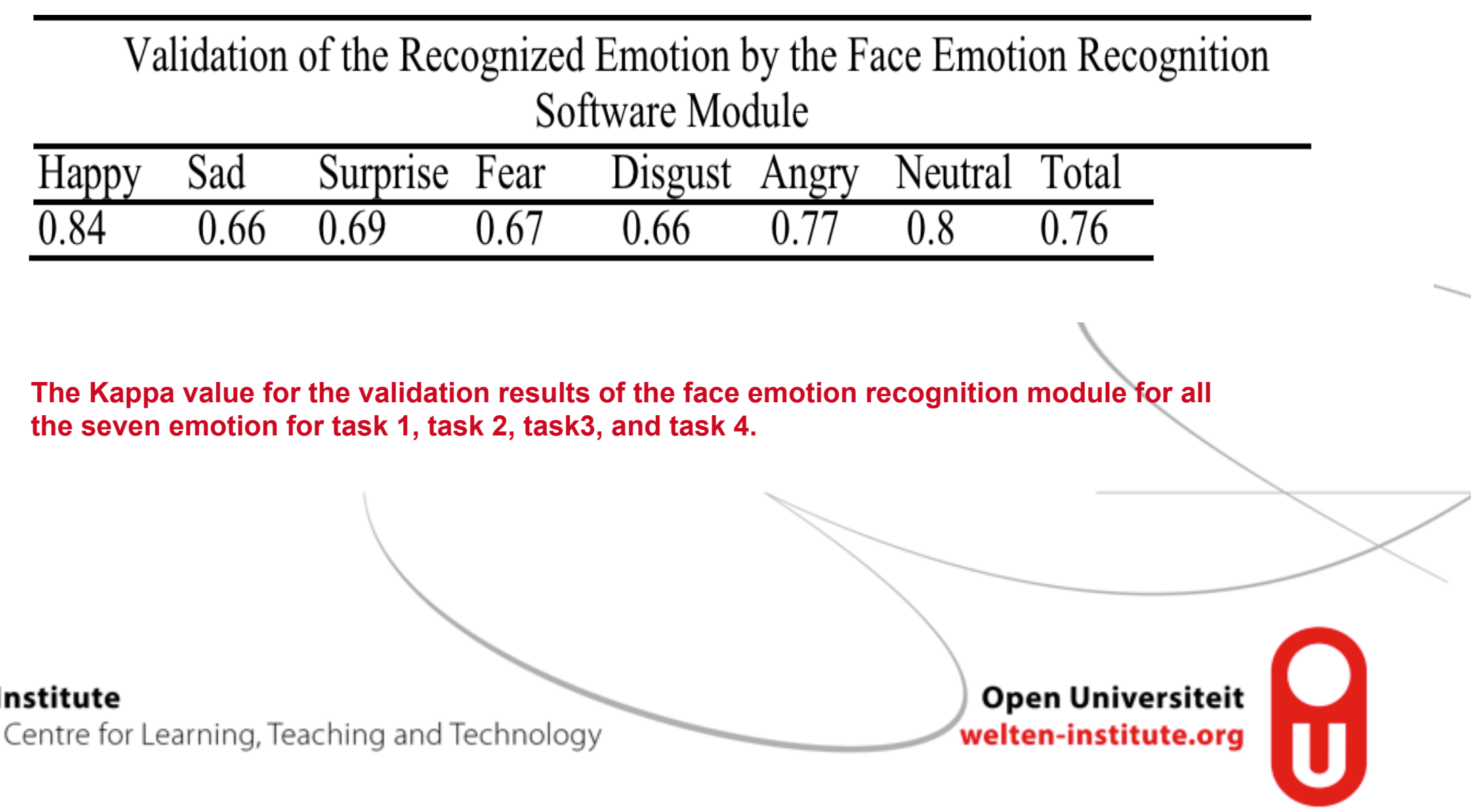




\section{Validation results of the voice emotion recognition software}

Validation of the Recognized Emotion by the Voice Emotion Recognition Software Module

\begin{tabular}{lccccccc}
\hline Happy & Sad & Surprise & Fear & Disgust & Angry & Neutral & Total \\
\hline 0.63 & 0.50 & 0.51 & 0.48 & 0.41 & 0.50 & 0.71 & 0.58 \\
\hline
\end{tabular}

The Kappa value for the validation results of the voice emotion recognition module for all the seven emotion for task 1, task 2, task3, and task 4. 


\section{Validation results of the integration of the two software artifacts}

\begin{tabular}{lcllllll}
\hline \multicolumn{7}{c}{ Validation of the Recognized Emotion by the Face and the Voice Emotion } \\
Recognition Software Modules \\
\hline Happy & Sad & Surprise & Fear & Disgust & Angry & Neutral & Total \\
\hline 0.68 & 0.50 & 0.53 & 0.50 & 0.43 & 0.55 & 0.73 & 0.61 \\
\hline
\end{tabular}

The overall Kappa value for the validation results of the face and the voice emotion recognition software modules for all the seven emotion for task 1, task 2, task3, and task 4 . 


\section{Multimodal fusion of the two software modules}

1. Linear weighted fusion method, which is a type of rule-based fusion

$$
\begin{aligned}
& V_{m,} 1 \leq m \leq n \\
& V=\frac{1}{n} \sum_{m=1}^{n} w_{m} \times V_{m}
\end{aligned}
$$

\section{Welten Institute}




\section{The overall accuracy of the multimodal fusion}

\begin{tabular}{|c|c|c|c|c|c|c|c|c|}
\hline \multirow{8}{*}{ 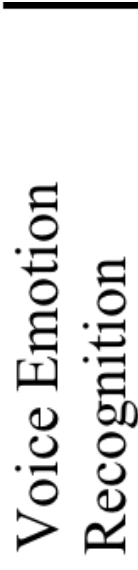 } & \multicolumn{8}{|c|}{ Face Emotion Recognition } \\
\hline & & Happy & $\mathrm{Sad}$ & Surprise & Fear & Disgust & Angry & Neutral \\
\hline & $\overline{\text { Happy }}$ & $89.7 \%$ & $56 \%$ f & $79 \% f$ & $58 \%$ f & $75 \% \mathrm{f}$ & $83 \%$ f & $90 \% \mathrm{f}$ \\
\hline & Sad & $80 \%$ f & $74.4 \%$ & $79 \%$ f & $66 \% \mathrm{v}$ & $75 \% \mathrm{f}$ & $83 \%$ f & $90 \% \mathrm{f}$ \\
\hline & Surprise & $80 \%$ f & $56 \%$ f & $67.8 \%$ & $58 \% \mathrm{f}$ & $75 \%$ f & $83 \%$ f & $90 \% \mathrm{f}$ \\
\hline & Fear & $80 \%$ f & $56 \%$ f & $79 \%$ f & $50.3 \%$ & $75 \%$ f & $83 \%$ f & $90 \% \mathrm{f}$ \\
\hline & Disgust & $80 \% \mathrm{f}$ & $56 \% \mathrm{f}$ & $79 \% \mathrm{f}$ & $58 \% \mathrm{f}$ & $63 \%$ & $83 \% \mathrm{f}$ & $90 \% \mathrm{f}$ \\
\hline & Angry & $80 \%$ f & $63 \% \mathrm{v}$ & $79 \% \mathrm{f}$ & $63 \% \mathrm{v}$ & $75 \% \mathrm{f}$ & $100 \%$ & $90 \% \mathrm{f}$ \\
\hline & Neutral & $80 \% \mathrm{f}$ & $61 \% \mathrm{v}$ & $79 \%$ f & $61 \% \mathrm{~V}$ & $75 \% \mathrm{f}$ & $83 \% \mathrm{f}$ & $100 \%$ \\
\hline
\end{tabular}




\section{Results}

1. The overall accuracy of our face emotion recognition software based on the requested emotions and the recognized emotions is $75 \%$.

2. The overall accuracy of our voice emotion recognition software based on the requested emotions and the recognized emotions is $52 \%$.

3. Compare to our previous study, the accuracy of our voice emotion recognition dataset improved from $22.2 \%$ to $50 \%$.

4. There are two reasons for the obtained false results:

1. The malfunctioning of the software

2. The participants were unable to mimic the requested emotions accurately 


\section{Creating a serious game in EMERGO}

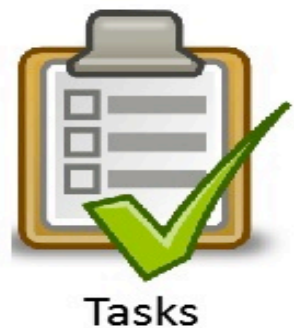

Score Counter: $5 / 100$

Completed Snippets: $1 / 20$

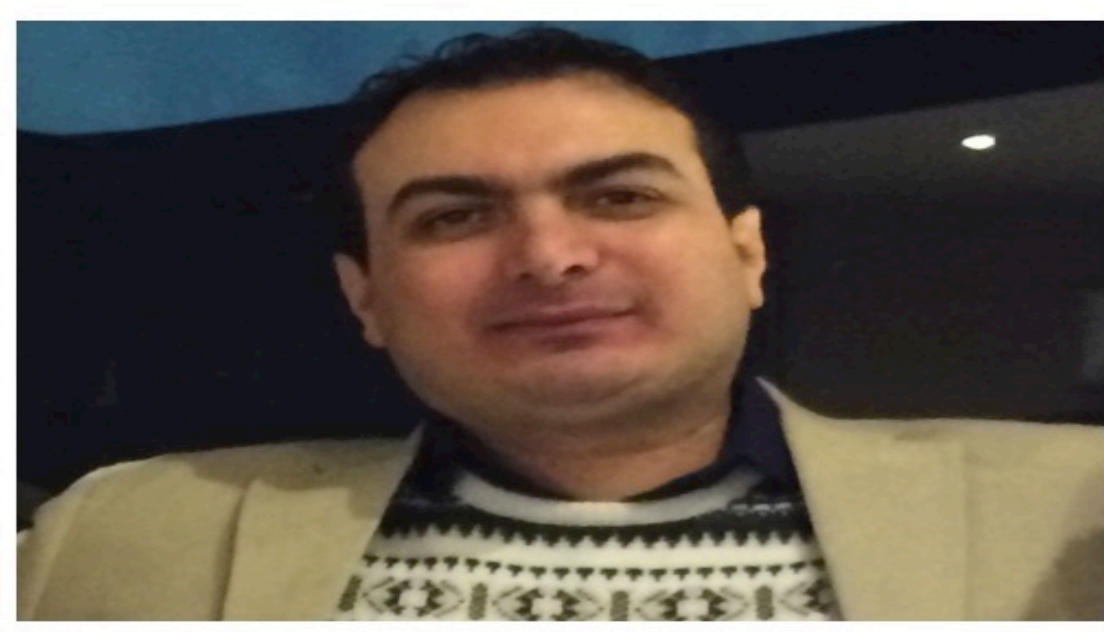

A recorded video of the conversation partner

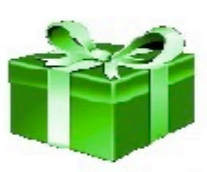

Reward

Detected Emotion from Face:

Happy

Detected Emotion from Voice:

Happy

The selected sentence and the emotion are:

- I'm pleased to announce that you've been selected! --- Neutral

I'm pleased to announce that you've been selected! --- Happy

- I'm pleased to announce that you've been selected! --- Surprise

- Human resources will contact you to review the details of your new contract. --- Neutral

- Human resources will contact you to review the details of your new contract. --- Happy

- Human resources will contact you to review the details of your new contract. --- Surprise

You can now continue by pressing Next button. 


\section{Thank you}

\section{Kiavash Bahreini}

$\mathrm{PhD}$ Candidate at Welten Institute

Research Center for Learning, Teaching and Technology

Open University of the Netherlands

$\triangle$ kiavash.bahreini@ou.nl

in http://nl.linkedin.com/pub/kiavash-bahreini/29/9b6/93

http://twitter.com/KiavashBahreini

kbsocialnetwork@gmail.com

+31(0) 614128485 